\title{
TOPOKLIMATSKA KARTA OBALNEGA PASU SLOVENSKE ISTRE
}

\author{
dr. Darko Ogrin", dr. Miroslav Vysoudil ${ }^{* * *}$ \\ *Oddelek za geografijo, Filozofska fakulteta Univerze v Ljubljani \\ Aškerčeva 2, SI-1000 Ljubljana \\ e-mail: darko.ogrin@ff.uni-lj.si \\ **Department of Geography, Faculty of Science, Palacký University Olomouc \\ 17. listopadu 12, CZ-77I46 Olomouc, Czech Republik \\ e-mail: miroslav.vysoudil@prfnw.upol.cz \\ Izvirni znanstveni članek
}

COBISS 1.01

\section{Izvleček}

V prispevku so prikazane osnovne topoklimatske značilnosti obalnega pasu Slovenske Istre, ki so rezultat splošnih podnebnih potez in specifičnih lokalnih razmer. Prostorsko najbolj razširjene topoklimatske enote so posledica razlik v osončenosti ter kombinacije lokalnih reliefnih danosti in rabe tal. Prikazane so na karti v merilu $1: 50.000$.

Ključne besede: lokalno podnebje, topoklima, topoklimatsko kartiranje, topoklimatska karta, termalni monitoring, Slovenska Istra, Slovenija

\section{TOPOCLIMATIC MAP OF THE LITTORAL ZONE IN SLOVENIAN ISTRIA}

\begin{abstract}
The paper presents the basic topoclimatic features of the littoral zone in Slovenian Istria which result from general climate features and specific local conditions. The most widely spatially spread topoclimatic units arise from differences in insolation and the combination of local landforms and land use. They are presented on the map at a scale of $1: 50,000$.
\end{abstract}

Key words: local climate, topoclimate, topoclimatic mapping, topoclimatic map, thermal monitoring, Slovenian Istria, Slovenia

\footnotetext{
* Prispevek je rezultat raziskovalnega projekta 'Lokalna klima in topoklimatsko kartiranje na primeru Slovenske Istre in osrednje Moravske' (projekt BI-CZ/10-11-011), ki sta ga financirala Ministrstvo za izobraževanje, šport in mladino Češke Republike in Ministrstvo za visoko šolstvo, znanost in tehnologijo Republike Slovenije.
} 


\section{UVOD}

Z izrazom topoklima označujemo specifične lokalne podnebne poteze, ki se oblikujejo pod vplivom značilnosti Zemljinega površja, predvsem reliefnih danosti (nadmorska višina, ekspozicija, naklon površja, reliefna izoblikovanost) in rabe tal (urbanizirane, gozdne, kmetijske, vodne površine, ipd.). Osnovne poteze pa so odvisne od regionalnih in tudi globalnih podnebnih razmer.

Raziskavo smo osredotočili na obalni pas, to je na območje, ki sega do okoli $10 \mathrm{~km}$ v notranjost Slovenske Istre. Velikost območja je narekovalo merilo topoklimatske karte (1 : 50.000; slika 8), ki predstavlja sintezo raziskave.

Raziskovanje vpliva lokalnih pokrajinskih razmer na podnebje ima v slovenski geografiji dolgo tradicijo. Študije so bile usmerjene na raziskovanje vpliva reliefa na lokalno podnebje (D. Ogrin, 2000; M. Ogrin, 2003), raziskovanje vpliva konkavnih oblik reliefa na minimalne temperature zraka (Gams, 1972; Žiberna, 1999; M. Ogrin in sod., 2006; M. Ogrin, 2007; Ortar in sod., 2010) in oblikovanje termalnega pasu (Gams, 1996; D. Ogrin, 2005; 2007; Žiberna, 1992). Raziskovali so odnos med reliefom in Sončevim obsevanjem (Gabrovec, 1996) in pojav mestne klime (Žiberna, 1991; Jernej, 2000; Konovšek, 2006). Manjšo tradicijo ima v slovenskem prostoru topoklimatsko kartiranje in izdelovanje topoklimatskih kart (D. Ogrin, 2008; Selčan, Tomić, 2010 - Ortarjeva karta Vpliv reliefa na podnebje), npr. v primerjavi s Srednjo Evropo, kjer je ta del klimatogeografije zelo razvit (Mičietová, Pavličko, 2000; Sulzer, 2002; Polčák, 2000; Quitt, 1965; 1990; 1994; Vysoudil, 1993; 1997; 2000; idr.).

Rezultati raziskave, ki so prikazani v prispevku, so plod sodelovanja med Oddelkom za geografijo Filozofske fakultete Univeze v Ljubljani in Oddelkom za geografijo Fakultete za naravoslovje Palackýjeve univerze v Olomoucu (Češka). K raziskavi so veliko pripomogli študenti drugega letnika geografije, ki so v okviru terenskih vaj iz Fizične geografije v študijskih letih 2005/06 do 2008/09 opravili številne meritve in opazovanja. Prav tako tudi študenti tretjega letnika v okviru kabinetnih vaj in seminarjev iz Fizične geografije Slovenije (mentorji: I. Mrak, M. Ogrin, D. Ogrin). Vsem sodelujočim se avtorja prispevka najlepše zahvaljujeva za trud. Zahvala gre tudi kartografinji Tanji Koželj na Oddelku za geografijo FF UL za pripravo topoklimatske karte.

\section{METODOLOGIJA}

V metodološkem smislu lahko ugotavljamo topoklimatske značilnosti, pri katerih so pomembne predvsem razmere pri površju (aktivna plast), kjer poteka energijska izmenjava med površjem in ozračjem, s podrobnimi terenskimi meritvami in opazovanji (neposredne metode) ali pa s posrednimi metodami. Pri našem delu smo uporabili kombinacijo obojega. Sledili smo metodologiji, ki se je uveljavila pri topoklimatskih raziskavah v Srednji Evropi (Quitt, 1965; 1994; Vysoudil, 1993; 2000; 2009; Polčák, 2000; 2001), in jo ustrezno prilagodili lokalnim razmeram v Slovenski Istri. Pri neposrednem spoznavanju lokalnih podnebnih razmer smo uporabili rezultate terenskega dela, ki sta ga predhodno opravila D. Ogrin (1995) ter D. Ogrin in Mužina (2005) ter 
rezultate opazovanj in meritev, ki so bile opravljene posebej za potrebe te raziskave. Zaradi pomena razmer pri površju za topoklimatske značilnosti večina meritev ni bila opravljena na standardni višini (te meritve so bolj reprezentativne za regionalne razmere), ampak nižje. Temperaturo zraka smo merili na 1,5 do $1,8 \mathrm{~m}$ nad površjem, veter na 1,8 do 2,5 m nad površjem, zastrtost obzorja zaradi reliefa in arhitektonskih ovir na 1,6 do $1,8 \mathrm{~m}$ nad tlemi.

S posrednimi metodami lahko sklepamo na lokalne podnebne poteze s pomočjo analize značilnosti površja, ki smo jo naredili s pomočjo GIS orodij. Pri reliefu smo upoštevali konkavnost, konveksnost, naklon in ekspozicijo. Pomagali smo si z digitalnim modelom višin $12,5 \mathrm{~m}$. Vpliv vegetacijskih razmer (gozd, trajni kmetijski nasadi, njive, travniki, slabo in neporaščeno površje) in rabe tal (gosto in redko pozidane površine, vodne površine) na podnebje smo ugotavljali s pomočjo Evidence dejanske rabe kmetijskih in gozdnih zemljišč (MKGP, 2010). V veliko pomoč pri sklepanju na temperaturne razmere ozračja pri tleh so nam bili tudi termalni posnetki površja. Ti so bili za potrebe te raziskave narejeni s prenosno infrardečo kamero (Fluke Ti55 IR fusion technology). Termalni posnetki so nam služili pri identifikaciji območij, ki imajo podobne temperaturne značilnosti aktivnega dela površja (sliki 1 in 2), kar nam je bilo v pomoč pri izločanju topoklimatskih enot pri topoklimatskem kartiranju (Vysoudil, D. Ogrin, 2009).

Slika 1: Razlike v temperaturi različnih tipov aktivnega dela površja na profilih med Tinjanom in Kubedom (termalni posnetek in njegova obdelava: M. Vysoudil)

Fig.1: Temperature differences of various types of the active surface part along the profile between Tinjan and Kubed (thermal image and its processing: M. Vysoudil)

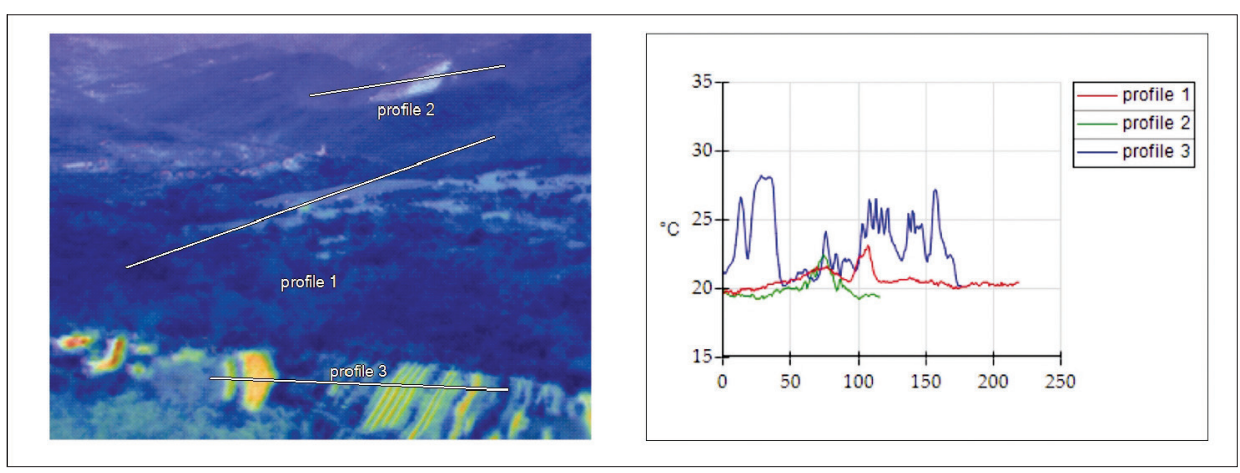


Slika 2: Razlike v temperaturi različnih tipov aktivnega dela površja na profilih med Socerbom in Miljskim polotokom (termalni posnetek in njegova obdelava: M. Vysoudil)

Fig. 2: Temperature differences of various types of the active surface part along the profile between Socerb and the Muggia peninsula (thermal image and its processing: M. Vysoudil)

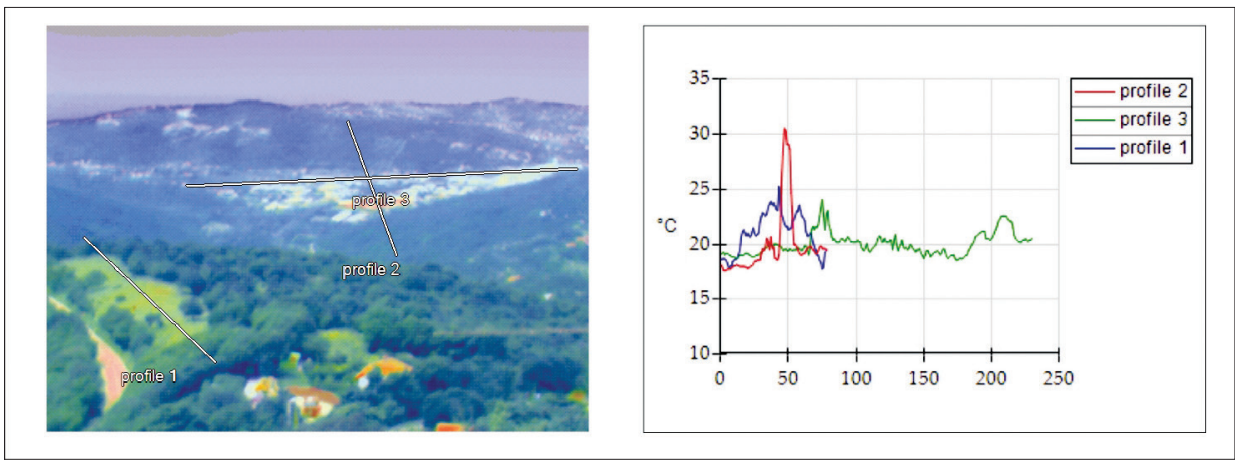

\section{TOPOKLIMATSKE RAZMERE IN TOPOKLIMATSKA KARTA}

\section{I. Lokalne razlike $\mathbf{v}$ osončenosti}

Obalni del Slovenske Istre je večinoma blago razgiban, zato lokalno ni večjih razlik v obsijanosti in prejeti energiji Sončevega sevanja. Glede na aprilske razmere, ki so dober pokazatelj povprečnih letnih razmer, je večina obravnavanega območja normalno obsijanega. Po izrazito boljši, oziroma slabši osončenosti izstopajo le najbolj strmi prisojni oziroma osojni predeli, vključno s klifi (preglednica 1). Južna, jugovzhodno in jugozahodno usmerjena pobočja z naklonom nad $20^{\circ}$ imajo zelo dobro osončenost. Taka so npr. prisojna pobočja pod Tinjanom, pod Šmarjami in Pomjanom, pod Padno, Kortami, Novo vasjo in Sv. Petrom. Severna, severovzhodna in severozahodna pobočja z naklonom nad $20^{\circ}$ so zelo slabo obsijana, še posebej v zimskem času, ko je Sonce nizko nad obzorjem. Takih predelov je več kot predelov z zelo dobro osončenostjo. Izstopajo večja območja osoj med Šmarjami in Babiči, pod Padno in Novo vasjo, južno pobočje Strunjanske doline s Strunjanskim klifom ter severno pobočje pod Gažonom.

Preglednica 1: Vpliv naklona in ekspozicije površja na osončenost (Vysoudil, 1993)

Table 1: The influence of inclination and exposition of surface on insolation (Vysoudil, 1993)

\begin{tabular}{|l|l|l|l|}
\hline \multirow{2}{*}{ Naklon $\left(\mathrm{v}^{\circ}\right)$} & Ekspozicija & Vzhod in zahod & Sever \\
\cline { 2 - 4 } & Jug & normalna & normalna \\
\hline Pod 5 & normalna & normalna & slaba \\
\hline 5 do 10 & dobra & normalna & slaba \\
\hline 10 do 15 & dobra & normalna & zelo slaba \\
\hline 15 do 20 & zelo dobra & dobra & zelo slaba \\
\hline Nad 20 & zelo dobra & & \\
\hline
\end{tabular}


Podobno sliko kaže tudi karta povprečne letne količine energije kvaziglobalnega obsevanja (Gabrovec, Kastelec, 1998, str. 105), ki prikazuje vzajemni vpliv astronomskih, atmosferskih in reliefnih dejavnikov na trajanje in energijo Sončevega obsevanja. Po tej karti prejme večji del obalnega pasu Slovenske Istre letno med 4400 in $4800 \mathrm{MJ} / \mathrm{m}^{2}$. Nad $4800 \mathrm{MJ} / \mathrm{m}^{2}$ dobijo le strma in izrazito prisojna pobočja, manj kot $4400 \mathrm{MJ} / \mathrm{m}^{2}$ pa strma in izrazito osojna pobočja in proti severu obrnjeni klifi (med Izolo in Koprom, med Strunjanom in Izolo, med Piranom in Strunjanom). Malo energije prejmejo ti predeli zlasti pozimi, ko je Sonce nizko nad ravnino horizonta. Na mikronivoju skrajšujejo trajanje obsevanja in zmanjšujejo količino prejete energije tudi rastlinstvo in visoke stavbe $\mathrm{v}$ gosto pozidanih naseljih, še posebej v zelo strnjeno pozidanih historičnih centrih vseh treh obalnih mest, ki oblikujejo posebno mikroklimo.

Klifi so zelo specifična topoklimatska kategorija, ne samo zaradi orientacije in z njo povezane dobre oziroma slabe osončenosti in posledično temperaturnih razlik, ampak tudi zaradi njihovega modificiranja zračnih tokov. S svojo višino in strmino tvorijo izrazita privetrja in zavetrja. Zaradi specifičnega aktivnega površja, ki je večinoma brez ali z malo vegetacije, imajo tudi svojstven temperaturni režim z velikimi temperaturnimi amplitudami.

Glede na meritve poteka realnega obzorja na več kot 50 reprezentativnih točkah obalnega dela Slovenske Istre, višina obzorja skrajšuje teoretično možno direktno Sončevo obsevanje na temenih flišnih hrbtov za pol do ene ure na dan, na obalnih ravnicah okoli eno uro, nekoliko več pozimi. V dnu dolin je obsevanje za 2 do 4 ure krajše od teoretično možnega. Izjema so nekatere ozke grape in območja tik pod strmimi pobočji, vključno z abrazijskimi ravnicami pod severno orientiranimi klifi. Nekateri predeli naštetih območij okoli zimskega obrata nimajo direktne insolacije, poleti pa je sonca za 4 do 5 ur manj (slika 3). 
Slika 3: Trajanje Sončevega obsevanja ob enakonočju, poletnem in zimskem obratu v Strunjanskih solinah, v dolini Drnice pod Padno, na rtu Debelega rtiča in na Ljubljanski ulici v Izoli. Sonce je nad obzorjem, ko poteka njegova pot izven obarvanega dela grafikona

Fig. 3: Duration of insolation at equinox and summer and winter solstices in the saltpans of Strunjan, in the Drnica valley below Padna, at the cape of Debeli rtič and in Ljubljanska ulica (street) in Izola. The sun is above the horizon when its way runs outside the coloured section of the graph

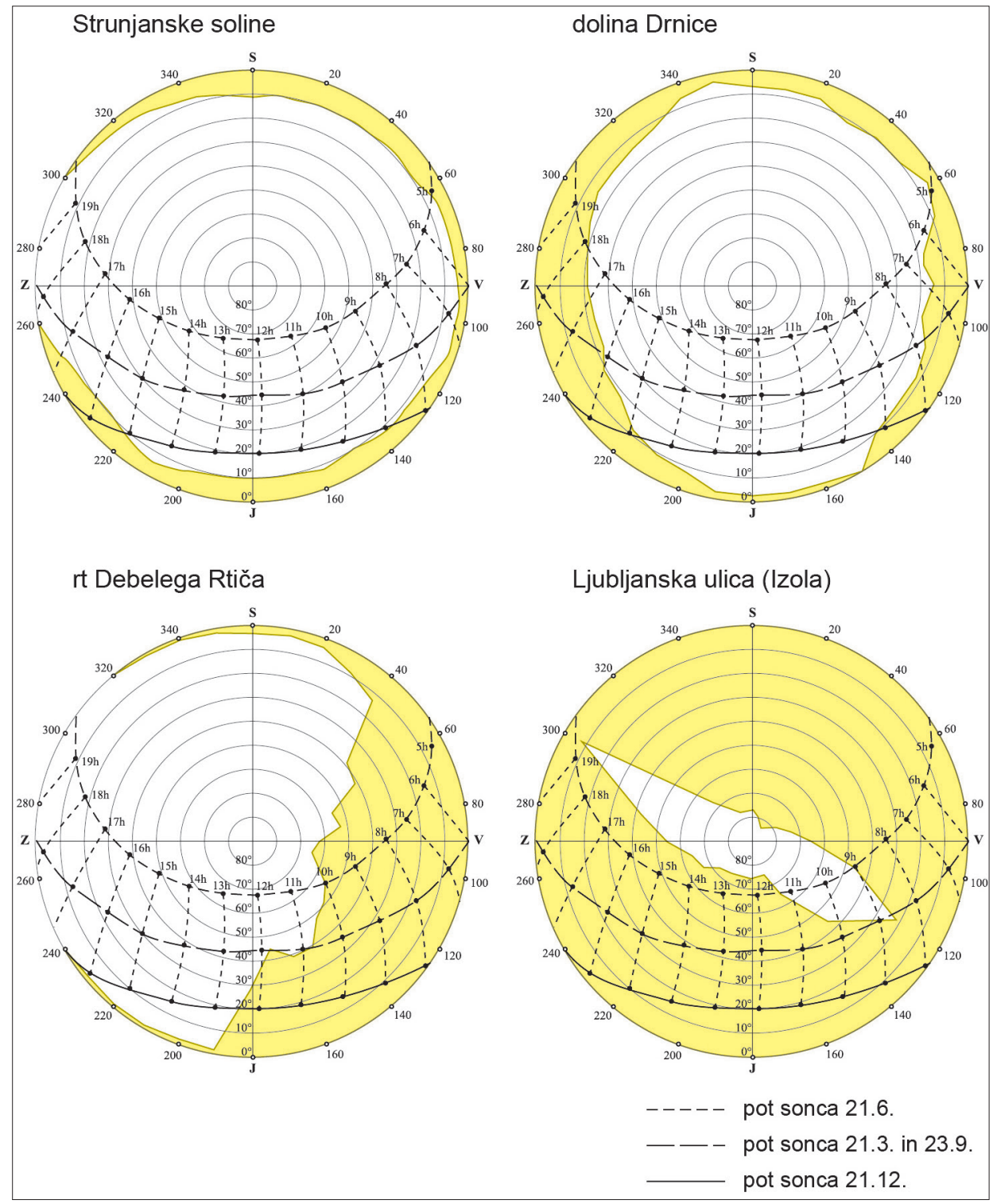




\subsection{Topoklimatski temperaturni pojavi}

Razporejanje temperature zraka je v Slovenski Istri odvisno od bližine morja, reliefnih danosti in od rabe tal. Pri reliefu izstopata višinska razporeditev in konkavnost površja, pomembna sta tudi naklon in ekspozicija. Z oddaljevanjem od morja proti višji notranjosti se temperature na splošno znižujejo, konkavni deli površja imajo nižje minimalne temperature zaradi temperaturnega obrata in jezer hladnega zraka. Južno orientirana pobočja so zaradi več prejete energije Sončevega obsevanja toplejša od severnih. Pri rabi izpostavljamo strnjeno pozidane površine, še posebej stare dele obalnih mest, ki imajo posebne temperaturne razmere. Gozd ima nekoliko bolj izravnan temperaturni režim kot negozdne in kmetijske površine. Posebno topoklimo imajo tudi soline in obalna mokrišča ter območja brez, oziroma z zelo redkim rastlinstvom.

\subsection{Temperaturni obrat $v$ konkavnih oblikah reliefa}

$\mathrm{Ob}$ radiacijskem tipu vremena nastane ponoči v konkavnih oblikah reliefa temperaturni obrat. Po močnih temperaturnih obratih izstopajo vale - fluviokraška podolja na prehodu kraškega v flišni del Slovenske Istre (Movraška in Gračiška vala), doline pregarskih ponikalnic (Malinska) in kraške kotanje na Podgorsko-Rakitovskem krasu. To so prava mrazišča. V Črnotijski vali (n. v. 385 m) je bila 19. 12. 2010, ob zelo dobrih pogojih za ohlajanje zraka, ko je površje prekrivala tudi snežna odeja, izmerjena do sedaj najnižja temperatura v Slovenski Istri, $-20,7^{\circ} \mathrm{C}$. Istega dne je bilo v Petrinjski vali $-20,5{ }^{\circ} \mathrm{C}$, v Malinski $-18,0^{\circ} \mathrm{C}$ in v Gračiški vali $-16,5^{\circ} \mathrm{C}$. Izraziti temperaturni obrati so tudi v spodnjih delih dolin (slika 4) in nad morjem, kamor se po dolinah steka hladen zrak iz zaledja. Ta se občasno opazi kot meglica, ki se širi proti zunanjim delom zalivov. Nad morjem se, predvsem v hladni polovici leta, pojavi temperaturni obrat tudi zaradi mrzlega morja, nad katerega doteka topel zrak.

Primerjava podatkov za meteorološki postaji Portorož-Beli križ (n. v. 92 m), na vrhu slemena, in v dolini ležeči Portorož-Letališče v Sečovljah (n. v. 2 m) za čas, ko so meritve potekale vzporedno, je pokazala, da je bil Beli Križ v obdobju 1987-1992 v letnem povprečju za skoraj $1{ }^{\circ} \mathrm{C}$ toplejši od Sečovelj. Razlika je bila še večja pozimi, ko so temperaturni obrati pogostejši in močnejši. Pri povprečni januarski temperaturi so bile Sečovlje hladnejše za skoraj $2{ }^{\circ} \mathrm{C}$, pri minimalni januarski temperaturi pa za več kot 3 ${ }^{\circ} \mathrm{C}$. Tudi v letnem povprečju minimalnih temperatur so bile Sečovlje na slabšem za nekaj več kot $2,5^{\circ} \mathrm{C}$. Toplotni obrat po dolinah obalnega pasu pomeni večjo in dlje trajajočo nevarnost pozeb, bolj vlažno ozračje ter pogostejšo roso in slano.

Po podatkih uradnih meteoroloških postaj so bile ob obali Tržaškega zaliva do sedaj zabeležene najnižje temperature v Kopru-Semedeli (n. v. 33 m) -12,8 ${ }^{\circ} \mathrm{C}(10.2 .1956)$, v Portorožu-Beli Križ $-9,3{ }^{\circ} \mathrm{C}(8.1 .1985)$, na Letališču Portorož v Sečovljah $-10,5^{\circ} \mathrm{C}(2$. 3. 2005) in v Trstu $-14,3{ }^{\circ} \mathrm{C}$ (11. 2. 1929). Ob hudem mrazu leta 1929, 1956 in 1985 so bile v Slovenski Istri tudi pozebe oljk. Sistematične meritve minimalnih temperatur v dolinah obalnega pasu v zimah 2007/2008 do 2010/2011 so pokazale, da so bili do sedaj izmerjeni ekstremi, ki so veljali za izjemne dogodke, zabeleženi v vsaki od opazovanih zim in da so minimalne temperature okoli $-10{ }^{\circ} \mathrm{C} \mathrm{v}$ dolinah obalnega pasu običajen 
pojav. Meritve so tudi pokazale, da se lahko poleti ob ugodnih pogojih za ohlajanje ozračja jutranje temperature spustijo tudi pod $10^{\circ} \mathrm{C}(1.8 .2007$ je bila npr. temperatura v Dragonji $7,0^{\circ} \mathrm{C}, 23.7 .2008$ pa na Biviu $9,0^{\circ} \mathrm{C}$ ).

Zaradi razlik $\mathrm{v}$ jakosti temperaturnih obratov ločimo znotraj te topoklimatske enote predele z manjšo konkavnostjo površja, to so spodnji deli dolin (obalne ravnice), kjer so temperaturni obrati šibkejši in plitvejši, in predele z bolj izrazito konkavnostjo (globlje in ožje doline v srednjem in zgornjem delu). Tu so temperaturni obrati močnejši, izrazitejše je tudi stekanje hladnega zraka proti obalnim ravnicam.

V spodnjih delih dolin in obalnih ravnicah vplivajo na topoklimo tudi vlažne talne razmere, zaradi katerih je višja vlažnost zraka in več kondenzacijskih pojavov v nočnem času. Čez dan se površje zaradi porabe energije za izhlapevanje segreva nekoliko počasneje. Ta enota vključuje soline (Sečoveljske in Strunjanske), nekdanje soline (Ankaranska in Koprska bonifika), ostala obalna mokrišča (Škocjanski zatok, jezeri v Fiesi) in območja $\mathrm{z}$ visoko talno vodo.

Slika 4: Minimalne temperature v dolini Badaševice ob radiacijskem vremenu (12. 5. 2009 od 5:14 do 6:13)

Fig. 4: Minimum temperatures in the Badaševica valley (12 May 2009; 05:14-06:13)

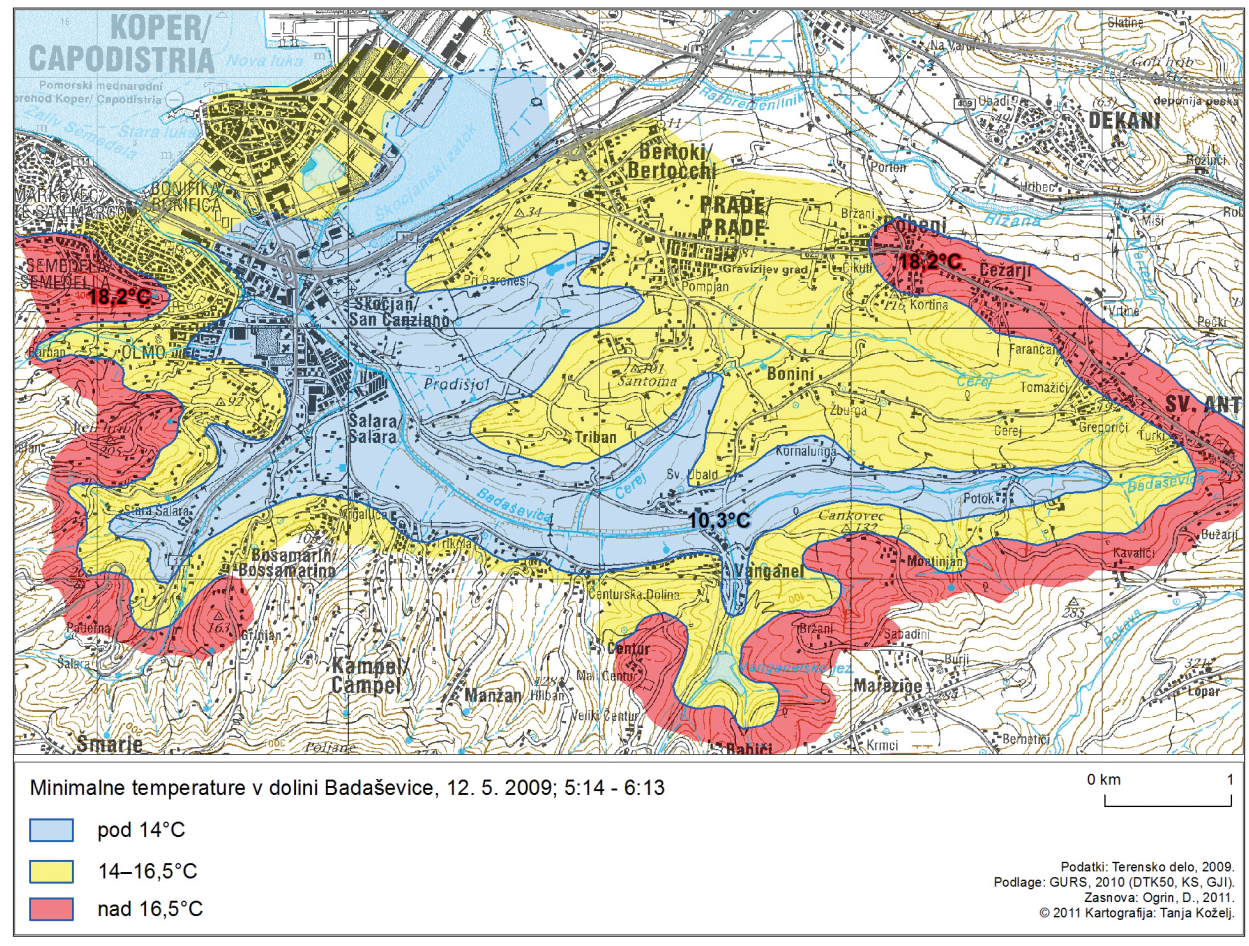




\subsubsection{Toplotni pas}

Bistveno višje minimalne temperature so na pobočjih in temenih nad dolinami v t.i. toplotnem (termalnem) pasu. Po rezultatih večkratnih profilnih meritev v različnih letnih časih je običajna razlika med predeli v inverzni plasti zraka in onimi nad njo 4 do $6{ }^{\circ} \mathrm{C}$, izjemoma tudi do $10{ }^{\circ} \mathrm{C}$ ali več. $Z$ vidika uspevanja toplotno zahtevnejših kultur, med katere sodi tudi oljka, je pomembno poznavanje višine inverzne plasti zraka. Ta zelo niha. V primerih močnih in dolgotrajnih temperaturnih obratov je lahko visoka tudi več kot $100 \mathrm{~m}$ (v takih primerih je običajno obalni pas Slovenske Istre pod meglo), navadno pa sega deset ali nekaj deset metrov nad dolinsko dno. Do kod segajo običajne inverzije in kje se začne toplotni pas, v katerem so minimalne temperature višje kot v dnu dolin, lahko sklepamo tudi iz razprostranjenosti oljčnikov. Skozi tisočletno tradicijo oljkarstva se je namreč izoblikovalo znanje o najugodnejših legah, kjer so optimalni pogoji za uspevanje oljke. Rezultati kartiranja v letih 2006-2009, predvsem starejših nasadov, so predstavljeni na sliki 5.

Oljčniki v obalnem pasu v okolici Hrvatinov, Ankarana, Bertokov, Pobegov, Izole in Strunjana nakazujejo začetek toplotnega pasu 15 do $20 \mathrm{~m}$ nad morjem, oziroma dolinskim dnom. V dolini Dragonje okoli vasi Dragonja, Sv. Peter in Krkavče se začnejo v povprečju okoli $15 \mathrm{~m}$ nad dnom doline. Bolj v notranjosti Slovenske Istre, kjer so doline hladnejše, se oljke začenjajo višje: v srednji in zgornji Rižanski dolini 20 do $40 \mathrm{~m}$ nad dolino, v okolici Padne in Šmarij pa okoli $50 \mathrm{~m}$ nad dolinskim dnom. V obalnem pasu sega toplotni pas do najvišjih temen flišnih hrbtov, v zgornji Rižanski dolini pa oljke nikjer ne presežejo višine $215 \mathrm{~m}$, kar pomeni vertikalni obseg termalnega pasu med 80 in $120 \mathrm{~m}$. Zaradi manjše izpostavljenosti burji in večje osončenosti so tri četrtine oljčnikov v južni, jugozahodni in jugovzhodni legi, največ v južni (okoli 35 \%). 
Slika 5: Toplotni pas, kakor ga nakazujejo oljčniki

Fig. 5: Thermal belt as indicated by olive groves

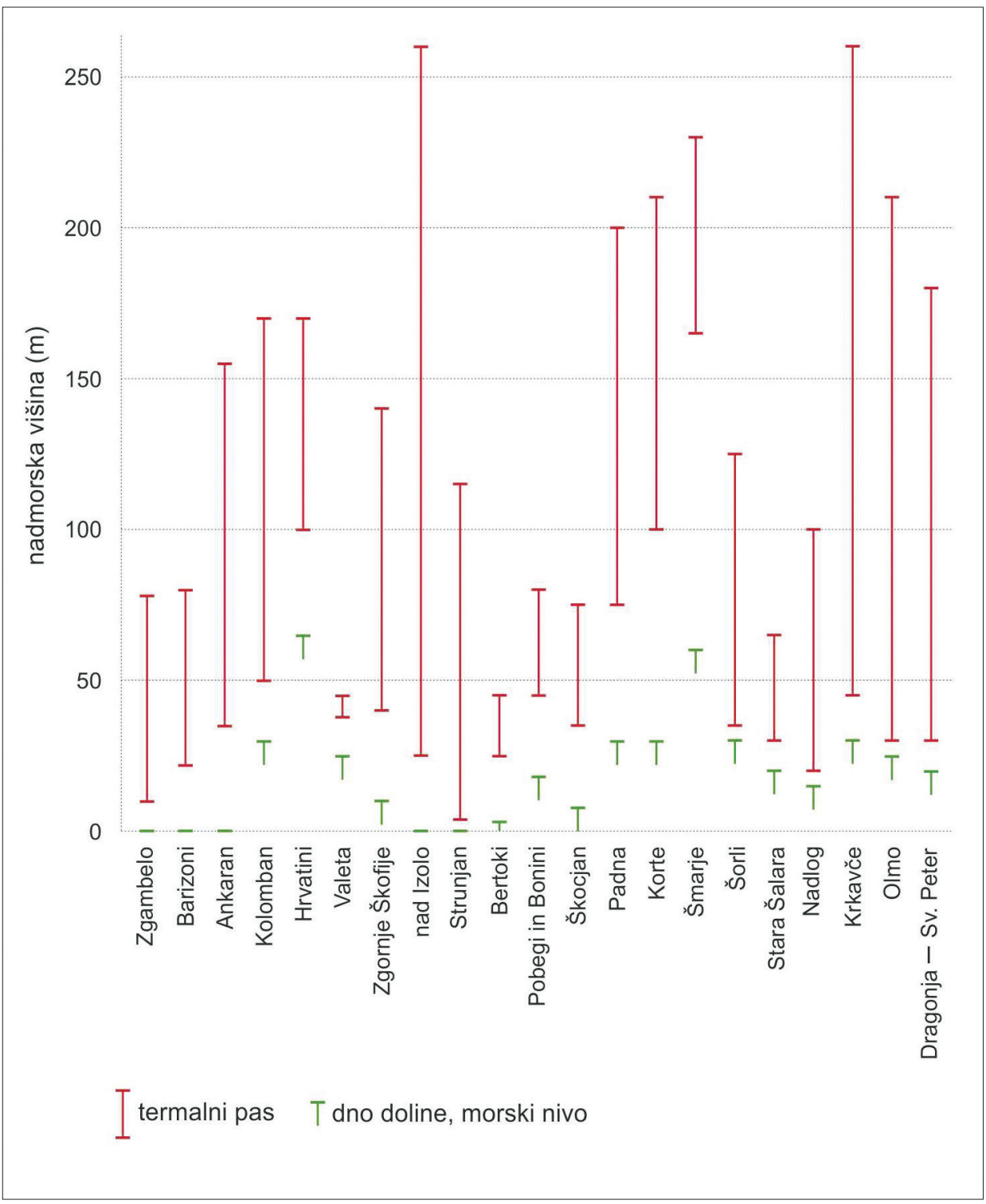

\subsection{Lokalne vetrovne razmere}

V nasprotju s konkavnimi predeli so izrazito konveksni predeli (temena flišnih hrbtov, izstopajoči vrhovi) bolj prevetreni. Izpostavljeni so vetrovom vseh smeri in hitrosti 
ter njihovim pokrajinskim učinkom. Na Tinjanu, Kortinci pri Marezigah, Poljanah nad Šmarjami, na grebenu med Gažonom in Segadici ter na Kaštelirju nad Kortami so opazne tudi zaradi vetra (burje) deformirane drevesne krošnje (D. Ogrin, 1995, str. 225).

Vpliv zračnih tokov različnih prostorskih dimenzij na lokalno podnebje je na topoklimatski karti razviden iz vetrovnih rož in puščic. S pomočjo vetrovnih rož, ki so narejene na osnovi podatkov uradnih meteoroloških postaj, lahko razberemo prevladujoče smeri vetrov na posameznih merilnih mestih, za katera pa žal nimamo podatkov za isto obdobje. Pri Sečovljah in Kopru je lepo razvidna odvisnost pogostosti vetra od lokalnih reliefnih razmer, oziroma usmerjenosti dolin in pobočij. Vetrovna roža za Beli Križ nad Piranom, ki leži na temenu Piranskega polotoka, pa dobro ponazarja razporeditev pogostosti vetrov na izrazito konveksnih predelih. Prevladujeta burja (severovzhodnik) in jugo (jugovzhodnik). Po pogostosti, moči in pokrajinskih učinkih izstopa burja. Burji je močno izpostavljen osrednji del Tržaškega zaliva, kjer poteka stržen tržaške burje, prav tako obalni rti in temena flišnih hrbtov z izpostavljenimi vrhovi. Zaradi prevladujoče smeri burje so ob tem vetru izrazito privetrna severovzhodna (severna), zavetrna pa jugozahodna (južna) pobočja.

Slika 6: Morje ob burji v Koprskem zalivu. Značilni so kratki, ozki in strmi valovi nepravilnih oblik, ki se lomijo in penijo. Nad Nanosom in Trnovskim gozdom je razpotegnjen burjin oblak, imenovan 'bandera' in tudi 'zástava' (foto: D. Ogrin)

Fig. 6: The sea in the Gulf of Koper during the bora. Typical are short, narrow and steep waves of irregular shapes which break and foam. Above the Nanos and the Trnovski gozd plateaus an elongated bora cloud extends, named 'bandera' (banner) or 'zástava' (flag) (photo: D. Ogrin)

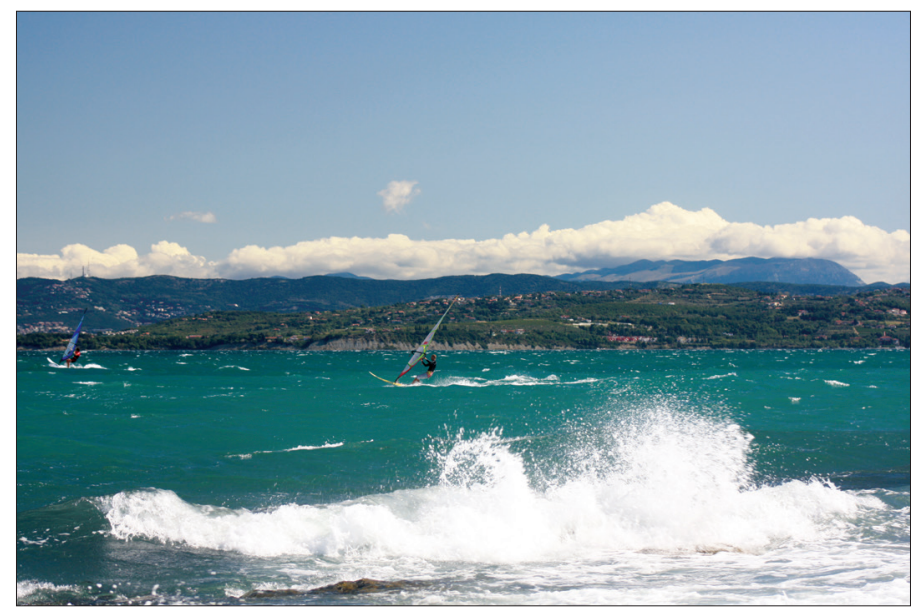


Ob stabilnem vremenu se razvije obalna zračna cirkulacija. Izrazitejša je njena dnevna komponenta, maestral, ki je poleti zaradi blaženja vročine pomemben za človekovo počutje. Maestralu, ki ima večinoma severozahodno smer, je najbolj izpostavljen ožji obalni pas, zelo izrazit je tudi na prvem nizu flišnih hrtov od Tinjana, Sv. Antona, Marezig in Šmarij do Malije in Kort. Nočna komponenta, burin, ni izrazita. V spodnjih delih dolin sovpada s tokovi hladnega zraka, ki se iz višjega zaledja po dolinah spuščajo k morju. Na topoklimatski karti so označeni tudi najpomembnejši viri onesnaževanja ozračja (terminal razsutih tovorov v luki Koper, kemična tovarna Kemiplas pri Dekanih (v zapiranju) in industrijska cona v Žavljah pri Trstu). Od njihove lokacije in z njo povezanimi vetrovnimi značilnostmi je odvisno, $v$ kateri smeri bodo vetrovi prenašali polutante.

\subsection{Vpliv rabe tal na topoklimo}

Za potrebe topoklimatske karte je bila raba tal določena s pomočjo Evidence dejanske rabe kmetijskih in gozdnih površin (MKGP, 2010). Zaradi velike pestrosti in mozaičnosti rabe ter merila karte $(1: 50.000)$ smo nekatere kategorije rabe, ki imajo podoben podnebni vpliv, združili. Pri tem, kakor tudi pri ugotavljanju temperaturnih značilnosti različnih tipov aktivnega dela površja in izločanju posameznih topoklimatskih enot, smo si pomagali s termalnimi posnetki površja. Analiza posnetkov je pokazala velike temperaturne razlike med posameznimi predeli v odvisnosti od tipa aktivnega površja (rabe tal), pa tudi od ekspozicije in naklona (slike 1, 2 in 7). 
Slika 7: Temperaturne značilnosti različnih tipov aktivnega dela površja: a) golega površja in gozda v osojah Osapske doline; b) različnih tipov kmetijske rabe (njiva, vinograd) pod Tinjanom, c) gosto pozidanega dela vasi, travnika, redko poraščenega pobočja in zatrepne doline pri Ospu; d) Sečoveljskih solin (termalni posnetki: M. Vysoudil)

Fig. 7: Temperature characteristics of different types of land use: a) barren area and forest on the shady side of the Osp valley; b) different types of agricultural use (field, vineyard); c) village, meadow, poorly overgrown area and steephead valley near Osp village; d) Sečovlje saltpans (Thermal images: M. Vysoudil)
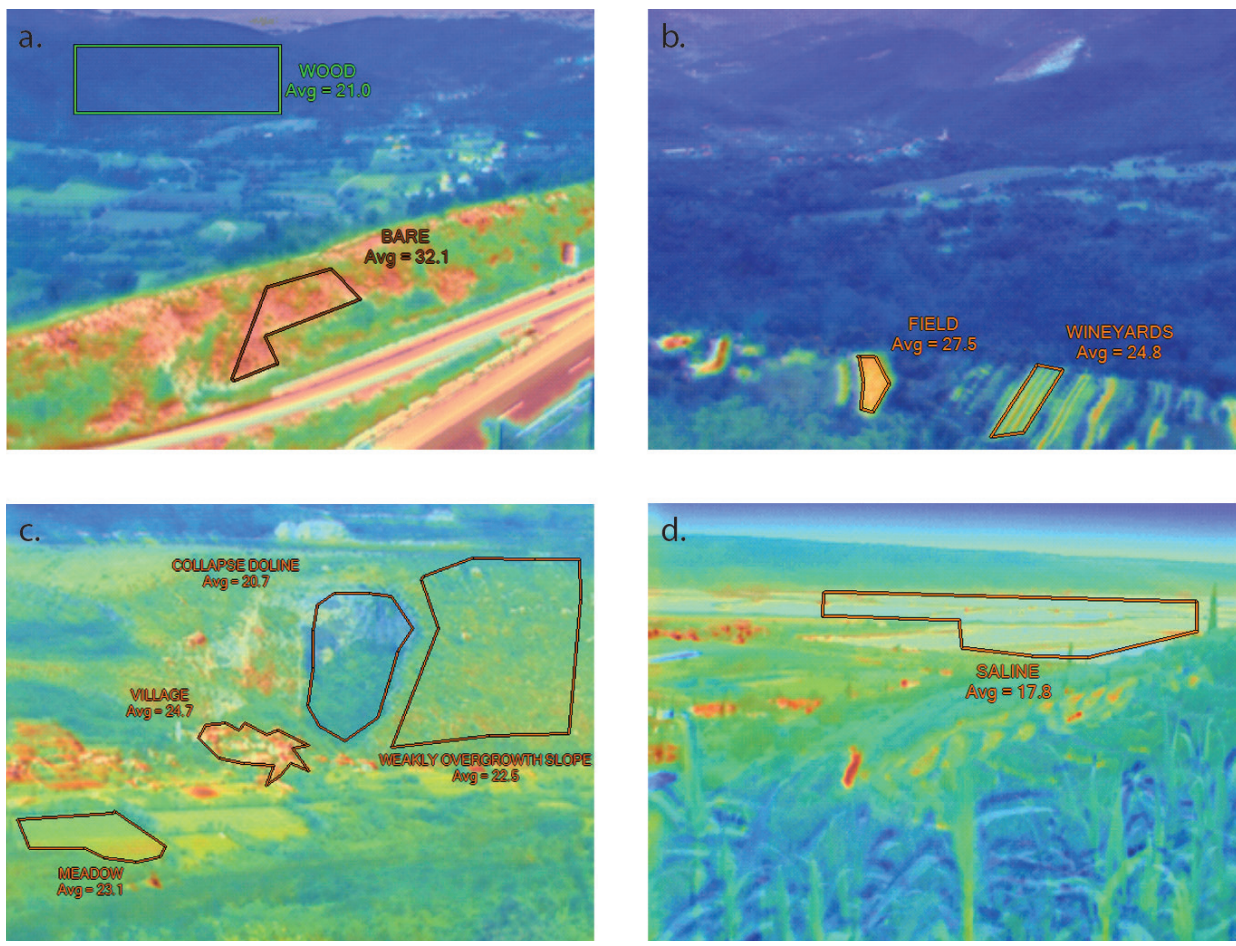

Pravi topoklimatski mozaik sestavlja preplet gozda, grmišč in travišč ter površin z redkim, oziroma brez rastlinstva in različnih kmetijskih rab (njive, trajni kmetijski nasadi). Za topoklimatske razmere, ki se oblikujejo nad temi površinami, je zelo pomembna gostota rastlinskega pokrova. Pri golih in slabo poraščenih površinah je aktivna plast pri tleh. V odvisnosti od barve, vlažnosti in poroznosti prsti (matične podlage) se površje čez dan zelo segreje, ponoči pa zelo ohladi, zato imajo take površine velike dnevne temperaturne amplitude. Če je površje prekrito z rastlinstvom (kulturnimi rastlinami), se ustvari posebno mikroklimatsko okolje, ki modificira absorbcijo Sončevega sevanja, izgube terestričnega sevanja in zračne tokove. Energija Sončevega sevanja se ne absorbira v eni plasti, ampak nekaj na vrhu rastlinskega pokrova, nekaj v pokrovu, del tudi v tleh. Pri zelo sklenjenem rastlinskem pokrovu je aktivna plast pri vrhu. V tem primeru so 
temperature podnevi nižje pri tleh, ponoči pa na vrhu rastlinskega pokrova. Kratkotrajne primerjalne meritve v gozdu (grmišču) submediteranskega tipa in na travniku na Debelem rtiču so pokazale, da so bile najvišje dnevne temperature v gozdu 0,5 do $1,5^{\circ} \mathrm{C}$ nižje kot na travniku, minimalne pa za $0,5^{\circ} \mathrm{C}$ višje. Hitrosti vetra so v rastlinskem pokrovu manjše, večja pa je turbulentnost. V rastlinskem pokrovu je večja tudi vlažnost zraka.

Svojstvene podnebne razmere imajo urbanizirane površine, kjer se zaradi vpliva pozidanih površin in delovanja človeka uveljavljajo značilnosti mestnega podnebja. Predvsem je pomembna zelo velika nehomogenost aktivnega dela površja (ulice, ceste, trgi, stavbe različnih dimenzij, zelene površine, tovarniške hale ipd.) in dejstvo, da je aktivno površje zaradi zgradb bistveno večje kakor pri nepozidanih površinah. Zaradi velikega pomena gostote pozidave ločimo topoklimo mest in ostalih gosto pozidanih površin ter topoklimo razpršeno pozidanih predelov. Posebne podnebne poteze imajo gosto pozidana srednjeveška jedra Kopra, Izole in Pirana, v nekoliko manjši meri tudi jedra nekaterih večjih gručastih vasi (Dekani, Škofije, Šmarje). Na nivoju ulic je npr. v teh naseljih močno skrajšano direktno Sončevo obsevanje (slika 3: Ljubljanska ulica v Izoli), poleti je čez dan nekoliko hladnejše, ponoči pa toplejše. Drugačne so razmere na nivoju streh, kamor je prestavljena aktivna plast površja, kjer se čez dan bistveno bolj ogreje, ponoči pa ohladi. Pomembno vlogo pri oblikovanju podnebnih razmer ima tudi veter, še posebej poletni maestral, če lahko po uličnih koridorjih vsaj delno prodre v mesto.

\subsection{Nekatere temperaturne značilnosti podnebja obalnih mest}

Strnjeno pozidana srednjeveška jedra vseh treh obalnih mest z ozkimi ulicami in visokimi stavbami oblikujejo posebno mestno podnebje, s specifičnimi temperaturnimi razmerami, kjer se prepletajo vplivi mesta, morja in lege. Mestno podnebje se razlikuje od okoliškega predvsem ob jasnem in mirnem vremenu. Raziskava, ki jo je v Piranu poleti 2007 naredila Guštinova (2007), je pokazala, da ob vročinskem valu 19. julija dve uri po sončnem zahodu pri tleh niso bili najtoplejši najbolj strnjeno pozidani deli mesta $\mathrm{V}$ starem delu Pirana, ampak prisojno pobočje pod obzidjem z redkejšo pozidavo. Ta predel mesta se je namreč čez dan močno segrel, medtem ko je bil stari del mesta z ozkimi ulicami in visokimi stavbami večinoma v senci. Razlika med najtoplejšimi in najhladnejšimi deli mesta je bila dobre $3{ }^{\circ} \mathrm{C}$. Predeli mesta ob morju so imeli srednje vrednosti, saj morje čez dan preprečuje pretirano segrevanje (ponoči pa ohlajanje). Drugačna je bila razporeditev temperature zraka v Piranu mesec kasneje, ko je čez dan pihala rahla burja. Ta je hladila predvsem severno obalo in bolj odprte, prevetrene dela mesta, zato je bilo zvečer najtopleje v najbolj strnjeno pozidanih delih mesta.

Tezo, da se v srednjeveških jedrih naših obalnih mest poleti pri tleh čez dan manj segreje, ker Sonce skoraj ne obsije tal ali posije le za kratek čas, so potrdile tudi meritve v Izoli 19. 7. 2007 med 15:30 in 16:30. Ti deli mesta so imeli za stopinjo do dve nižje temperature od predelov, kjer se je čutil vpliv maestrala. Najvišje (tudi do $5{ }^{\circ} \mathrm{C}$ v primerjavi s centrom) pa so bile temperature na večjih odprtih površinah $\mathrm{z}$ dobro osončenostjo (parkirišča, trgi, široke ulice) in v delih Izole z bolj redko pozidavo brez večjih zelenih površin. Ravno obratne kot čez dan so bile razmere naslednjo noč uro do dve pred 
sončnim vzhodom. Tedaj so bili gosto pozidani deli Izole najtoplejši (stavbe so oddajale čez dan akumulirano toploto), obod starega dela mesta pa je bil za dve do tri stopinje hladnejši. Drugačne kot pri tleh so temperature na nivoju streh in v višjih nadstropjih stanovanjskih hiš, kjer je osončenost boljša. Meritve v Piranu in Izoli so pokazale, da so tako čez dan kakor ponoči tu temperature za 2 do $4{ }^{\circ} \mathrm{C}$ višje kakor pri tleh.

Še bolj izrazit mestni toplotni otok v nočnem času kot pri Izoli smo odkrili v Kopru ob meritvah 30. 8. 2008 med 23:00 in 24:15. Srednjeveški Koper leži na rahli vzpetini (nekdanji otok), ki jo obdajata umetno podaljšani ravnici Rižane in Badaševice. Hladen zrak, ki se steka ob jasnih in mirnih nočeh po dolinah obeh rek iz višjega zaledja proti morju, oblije srednjeveški del mesta, zato je bil ta do $3{ }^{\circ} \mathrm{C}$ toplejši od nekoliko nižje in manj strnjeno pozidane okolice.

\subsection{Topoklimatska karta}

Topoklimatska karta obalnega dela Slovenske Istre (slika 8) je bila izdelana v merilu 1 : 50.000. Med pripravo karte se je to merilo izkazalo za pregrobo. Zaradi izrazite drobne razčlenjenosti površja Slovenske Istre in izredno mozaične sestave različnih rab ter z njimi povezanimi razlikami v temperaturi aktivnega dela površja merilo ni dopuščalo preglednega prikaza vseh podrobnosti topoklimatskih razmer. Ker smo želeli, da bi bila karta kljub temu zadovoljivo pregledna in berljiva, smo se odločili za določeno stopnjo generalizacije posameznih elementov površja, ki so pomembni za topoklimo (ekspozicija, naklon, vegetacija, raba). Zaradi tega je potrebno karto razumeti kot nekoliko posplošen prikaz topoklimatskih razmer obalnega dela Slovenske Istre. V uporabne namene, npr. kot pomoč pri izdelavi prostorskih načrtov in umeščanju dejavnosti v prostor, bi potrebovali karto v večjem merilu.

Osnovne topoklimatske enote izhajajo iz razlik v osončenosti in členitve površja na konkavne predele s pogostim temperaturnim obratom in konveksne predele $\mathrm{z}$ dobro prevetrenostjo. Nadaljnja členitev je odvisna od stopnje pozidave, poraščenosti površja in različnih kmetijskih rab. Te členitve pa nismo naredili pri topoklimi izrazito konveksnih predelov, ker tega nista dopuščala merilo karte in majhne površine, ki jih ta enota zavzema. Pri topoklimi konkavnih predelov je bila upoštevana tudi vlažnost površja (vodne, močvirne in solinarske površine, predeli z visoko talno vodo, mokrišča). Na topoklimatski karti je z vetrovnimi rožami prikazana pogostost posameznih vetrov, s puščicami pa so označeni predeli, ki so bolj izpostavljeni burji in maestralu ter tokovnice stekanja hladnega zraka po dolinah ob jasnem vremenu ponoči. 
Slika 8: Topoklimatska karta obalnega pasu Slovenske Istre

Fig. 8: Topoclimatic map of the littoral zone in Slovenian Istria

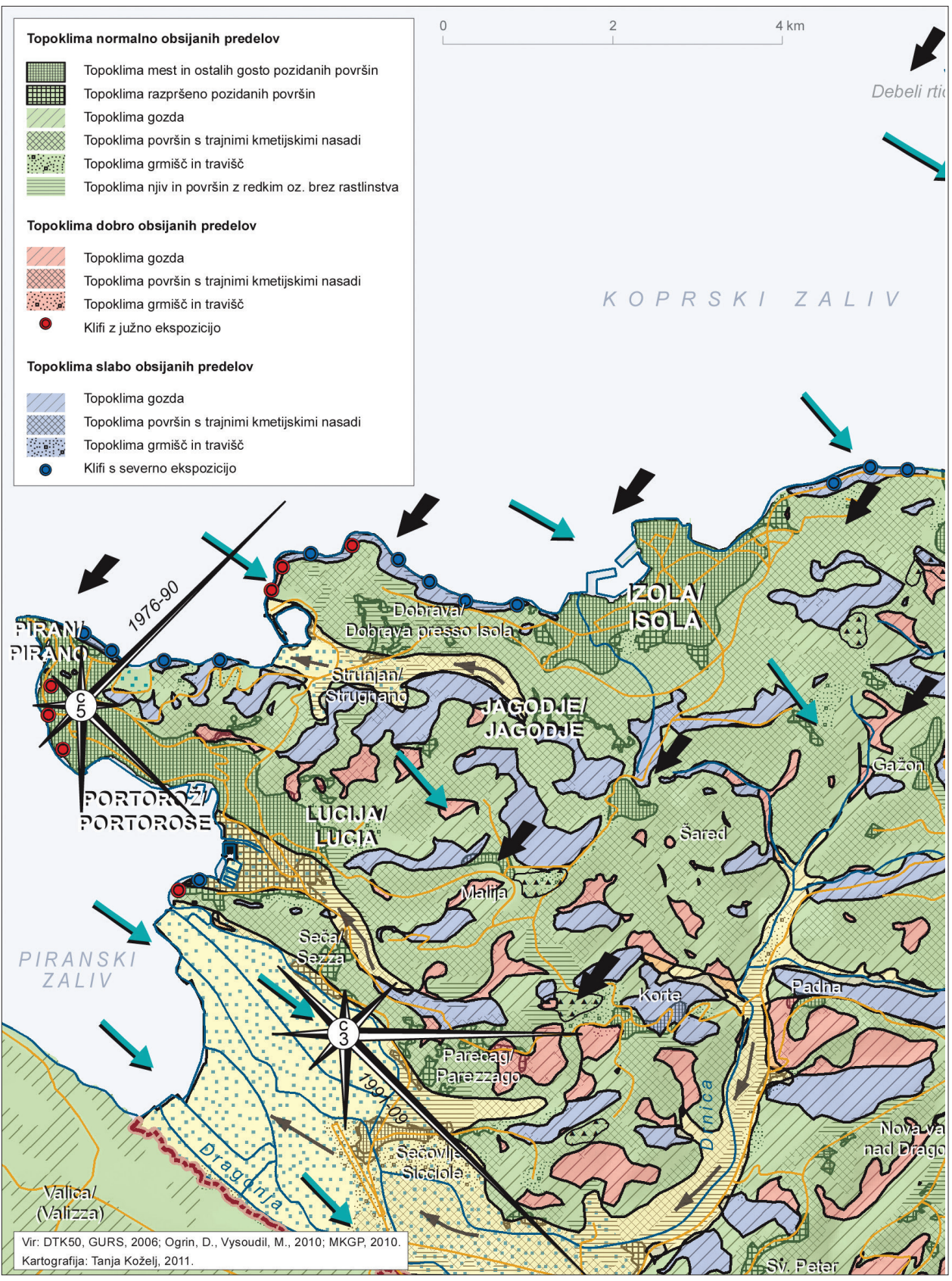




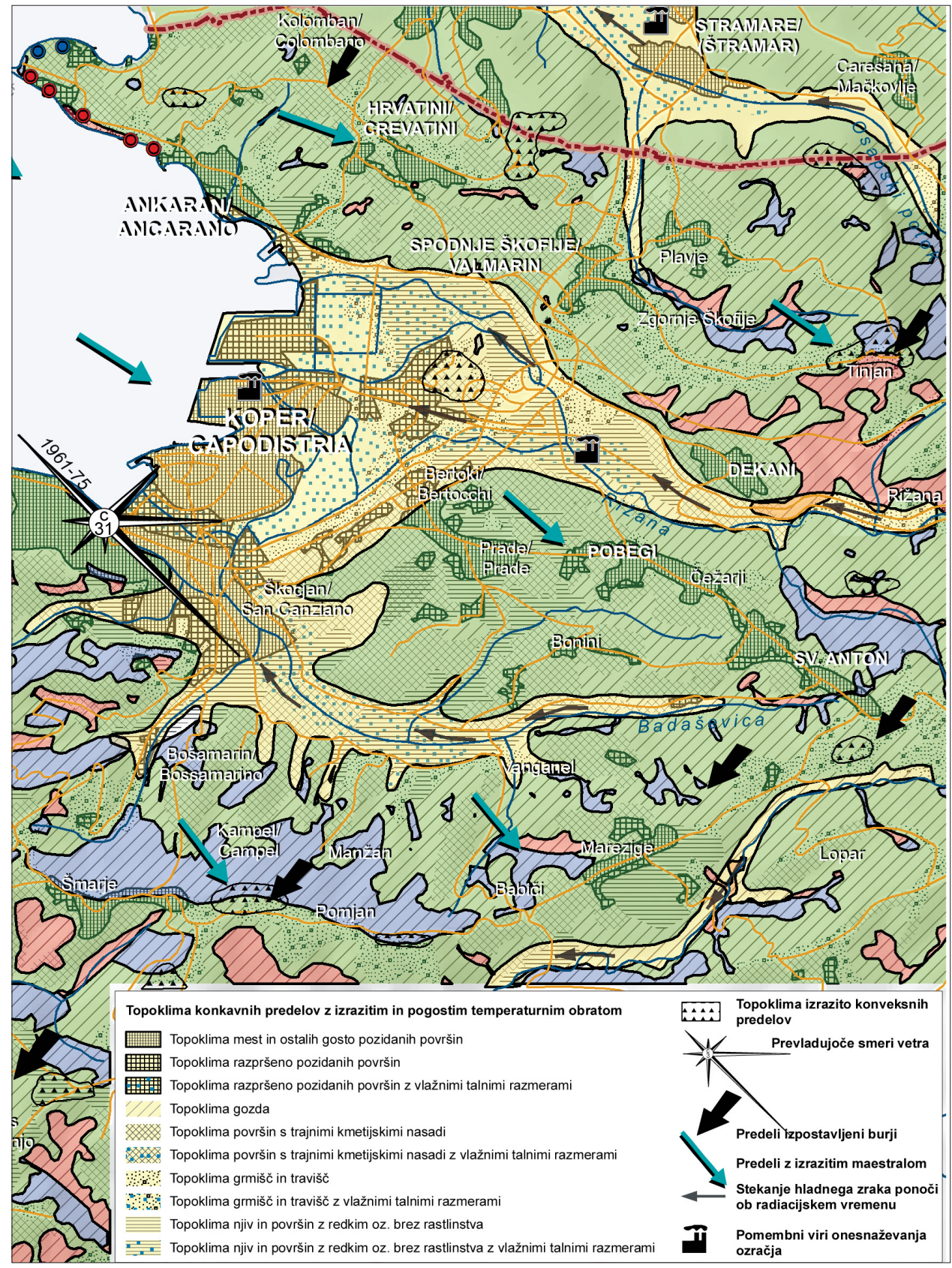




\section{SKLEP}

Topoklimatska karta obalnega dela Slovenske Istre predstavlja enega od prvih poskusov izdelave topoklimatske karte pri nas po metodologiji, ki jo je izoblikovala srednjeevropska šola topoklimatskega kartiranja. Metodologija, po kateri smo se zgledovali, je bila prilagojena posebnim lokalnim razmeram, med katerimi izstopa stik kopna in morja. Eden od ciljev topoklimatskega kartiranja je priprava ustreznih podlag za prostorsko in urbanistično planiranje ter za umeščanje različnih dejavnosti in objektov v prostor. Topoklimatske karte so nam v pomoč pri določanju območij, ki so primerna za posamezne kmetijske kulture, pri opozarjanju na predele, ki jih lahko prizadenejo nekateri nevarni vremenski pojavi (poledica, pozeba, megla, inverzija), pri izločanju območij, ki so potencialno ogrožena zaradi posameznih virov onesnaževanja zraka, ipd. Za tovrstne namene so seveda potrebne podrobnejše topoklimatske karte, izdelane v večjem merilu in prilagojene namenu uporabe. Predstavljena topoklimatska karta je zaradi uporabljenega merila in pestre pokrajinske sestave obravnavanega območja v določeni meri generalizirana in prikazuje predvsem splošne topoklimatske razmere.

\section{Viri in literatura}

Gabrovec, M., 1996. Solar radiation and diverse relief of Slovenia. Geografski zbornik, 34, str. 47-68. Ljubljana.

Gabrovec, M., Kastelec, D., 1998. Sončno obsevanje. V: Geografski atlas Slovenije. Ljubljana, DZS, str. 104-105.

Gams, I., 1972. Prispevek k mikroklimatologiji vrtač in kraških polj. Geografski zbornik, 13, str. 5-79. Ljubljana.

Gams, I., 1996. Termalni pas v Sloveniji. Geografski vestnik, 68, str. 5-38. Ljubljana.

Guštin, Š., 2007. Mestni toplotni otok Pirana. Seminarska naloga. Ljubljana, Filozofska fakulteta, Oddelek za geografijo, 22 str.

Jernej, S., 2000. Mestna klima Ljubljane. V: Ljubljana - geografija mesta. Ljubljana, LGD in Založba ZRC, str. 117-130.

Konovšek, A., 2006. Mezoklimatske razmere Šaleške doline in mestna klima Velenja. V: Šaleška in Zgornja Savinjska dolina. Zbornik 19. zborovanja slovenskih geografov. Velenje, ERICO, Inštitut za ekološke raziskave, str. 76-86.

Mičietová, E., Pavličko, P., 2000. Metodika tvorby topoklimatických máp v prostredí geoinformačných technológii. Kartografické listy, 8, str. 99-116. Bratislava.

MKGP, 2010. Evidenca dejanske rabe kmetijskih in gozdnih zemljišč. Raba_20100420). Medmrežje: http://rkg.gov.si/GERK (Citirano aprila 2011).

Ogrin, D., 1995. Podnebje Slovenske Istre. Knjižnica Annales 11. Koper, Zgodovinsko društvo za južno Primorsko, 381 str.

Ogrin, D., 1996. Podnebni tipi v Sloveniji. Geografski vestnik, 68, str. 39-65. Ljubljana.

Ogrin, D., 2000. Nekatere topoklimatske značilnosti razporejanja temperature zraka in burje v razgibanem reliefu Slovenije. Dela, 15, str. 125-138. Ljubljana. 
Ogrin, D., 2005. A contribution to the definition of thermal belt in Sub-pannonian Slovenia. Geographica Pannonica, 9, str. 4-8. Novi sad.

Ogrin, D., 2007. Uporabnost kartiranja vinogradov kot metode za ugotavljanje prostorskih značilnosti termalnega pasu. Dela, 28, str. 121-132. Ljubljana.

Ogrin, D., 2008. Splošne in lokalne podnebne značilnosti Bele krajine. V: Bela krajina in Krajinski park Lahinja. Ljubljana, Znanstvena založba FF, str. 71-90.

Ogrin, D., Mužina, D., 2005. Pokrajinskoekološke značilnosti območja med Kavčičem in Tinjanom. V.: Meje in konfini. Knjižnica Annales Majora. Koper, Univerzitetna založba Annales, str. 289-332.

Ogrin, M., 2003. Vpliv reliefa na oblikovanje nekaterih mikroklimatskih tipov v Sloveniji. Geografski vestnik, 75, 1, str. 9-24. Ljubljana.

Ogrin, M., 2007. The minimum temperatures in the winter 2006/07 in Slovenian frost hollows and cold basins. Dela, 28, str. 221-237. Ljubljana.

Ogrin, M., Sinjur, I., Ogrin, D., 2006. Minimalne temperature v slovenskih mraziščih pozimi 2005/2006. Geografski obzornik, 53, 2, str. 4-12. Ljubljana.

Ortar, J., Ogrin, M., Vertačnik, G., Sinjur, I., 2010. Primerjava temperaturnih razmer v mraziščih Reovce (Orjen), Valoviti do (Durmitor), Luknja in Mrzla Komna (obe Julijske Alpe) v meteorološki zimi 2007/2008. V: Geoekologija - XXI vijek, Teorijski i aplikativni zadaci. Zbornik referata GEOEKO 2010, str. 553-561. Žabljak-Nikšić.

Polčák, N., 2000. Možnosti spracovania mezoklímy a miestnej klímy v územiach s chýbajúcou klimatickou databázou na príklade Biosférickej rezervácie Východné Karpaty. Geografický časopis, 52, str. 181-191. Bratislava.

Polčák, N., 2001. Analýza teplotných inverzií v Banskej Bystrici na základe terénnych pozorovaní. V: Ekologická diverzita modelového územia Banskobystrického regiónu. Banská Bystrica, FPV UMB, Štátna ochrana prírody SR, Stredoslovenské museum, str. 55-65.

Quitt, E., 1965. Metody konstrukce mezoklimatických map. Sborník Československé společnosti zeměpisné, 3, str. 232-250. Praha.

Quitt, E., 1990. Methods, result and perspectives of topoclimatic mapping in Czechoslovakia. V: Problems of contemporary topoclimatology. Conference papers, 4. Warszawa, Institute of geography and spatial organization, Polish Academy of Science, str. 11-18.

Quitt, E., 1994. Topoclimatic map as a basis for atmosphere protection and regional development of the landscape. Moravian geographical reports, 2, str. 12-17. Brno.

Selčan, A., Tomić, T., 2010. Podnebje občine Tolmin. V: Občina Tolmin: Sotočje mladih možganov in aktualnih izzivov. 14. geografski raziskovalni tabor, Volče. Ljubljana, Društvo mladih geografov Slovenije, str. 49-55.

Sulzer, W., 2002. Climatological research and its possible contribution to regional planning in an Alpine environment. V: Global environmental change in Alpine regions recognition, impact, adaptation and mitigation. Cheltenham, Edward Elgar Publishing Ltd., str. 150-160.

Vysoudil, M., 1993. Topoclimatic mapping in Central Moravia (Czech Republic). Geografski vestnik, 65, str. 25-31. Ljubljana. 
Vysoudil, M., 1997. Bioclimate and air quality assessment in the cultural landscape by use topoclimatic maps. V: Biometeorology - Proceedings of $14^{\text {th }}$ International congress of Biometeorology, September 1-8, 1996. Ljubljana, International Society of Biometeorology in Slovensko meteorološko društvo, str. 311-316.

Vysoudil, M., 2000. Topoklimatické mapování: Od teorie k praxi. Geografický časopis, 52, 2, str. 2-13. Bratislava.

Vysoudil, M., 2009. Klasifikace místních klimatických efektů. Geografický časopis, 61,

3, str. 229-241. Bratislava.

Vysoudil, M., Ogrin, D., 2009. Portable infrared camera as a tool in topoclimatic research. Dela, 31, str. 115-127. Ljubljana.

Žiberna, I., 1991. Nekatere značilnosti mestne klime Maribora. Dela, 8, str. 72-84. Ljubljana. Žiberna, I., 1992. Vpliv klime na lego in razširjenost vinogradov na primeru srednjih Slovenskih goric. Geografski zbornik, 32, str. 51-139. Ljubljana.

Žiberna, I., 1999. Temperaturni obrat v hriboviti Sloveniji. Dela, 13, str. 237-248. Ljubljana.

\section{TOPOCLIMATIC MAP OF THE LITTORAL ZONE IN SLOVENIAN ISTRIA}

\section{Summary}

The term topoclimate designates for specific local climate conditions which occur under the influence of Earth's surface characteristics, mainly landforms and land use. However, the basic features depend on regional as well as global conditions. The research focused on the littoral part in Slovenian Istria. Topoclimatic characteristics were established by combining detailed field measurements and observations with indirect methods in which local climate features were established through the analysis of relief and vegetation characteristics and land use. The synthesis of the research is represented by the topoclimatic map of the littoral zone of Slovenian Istria at a scale of $1: 50,000$ (Fig. 8).

Most of the discussed area is normally sunlit since the surface is only slightly undulated. Outstanding in better or poorer insolation are only the steepest (over $20^{\circ}$ ) sunny or shady, respectively, areas, including the coastal cliffs. The cliffs constitute a distinct topoclimatic unit also because of their particular temperature regime, since they are but poorly overgrown, and due to the modified air currents. Relevant in view of topoclimate are the concave parts of the surface (valleys) where intense and frequent temperature inversions occur together with the related greater frequency of condensation phenomena, greater air humidity and greater frost hazard. In stable weather conditions cool air from the higher hinterlands also flows towards the sea along the valleys at night. In the bottom sections of valleys, in littoral plains, in the area of the active and abandoned saltpans, and on the coastal wetlands, topoclimate is also affected by the humid ground conditions.

In contrast to the concave areas, the explicitly convex areas are better aired. They are exposed to winds of all directions and speeds. Most important as to the effects in the 
landscape is the bora, to which the central part of the Gulf of Trieste is intensely exposed as well as the coastal capes and summits of the flysch ridges. During stable weather conditions sea breeze develops. Its daytime component - maestral - is more explicit and the most exposed to it is the narrow coastal belt and the first row of flysch ridges.

Specific climate features occur in urbanized areas where - due to the influence of built-up areas and human activity - the characteristics of urban climate prevail. Because of the significant influence of the density of built-up areas, two topoclimates are discerned: that of the towns and other densely built-up areas, and that of the areas with dispersed building-up. Particular climate features occur in densely built-up medieval cores of Koper, Izola and Piran, and to a slightly lesser degree also in the cores of some larger cluster villages. Solar radiation in streets is much shortened in these settlements, so that in summer they are slightly cooler in daytime and warmer at night. An important role in the formation of climate conditions in littoral towns is played by wind - maestral in summer - especially if it is free to blow along the street corridors into the town.

A true topoclimatic mosaic consists of the combination of forests, bushes and grasslands, the areas with sparse or without vegetation, and areas with diverse agricultural land use. Very important for the topoclimatic conditions which develop above these surfaces is the density of vegetation cover. In barren and poorly overgrown areas the active surface layer occurs just above the ground. Depending on the color, humidity and porosity of soil (parent material) the surface warms intensely during the daytime and cools intensely during the night, therefore great daily temperature amplitudes occur in such areas. If the surface is covered with vegetation (cultural plants), a special microclimate atmosphere develops which modifies the absorption of solar radiation, terrestrial radiation and air currents. The energy of solar radiation is not absorbed in a single layer, but part of it is absorbed in the top of vegetation cover, part of it in the cover itself, and part of it also in the ground. In the case of a non-interrupted cover, the active layer occurs at the top; then the temperatures in daytime are lower on the ground level, and at night on the top of the vegetation cover. In the vegetation cover wind speeds are lower while turbulence is stronger. Air humidity is also higher in vegetation cover. The fact that microclimate conditions on the surface are significantly different, depending on the type of vegetation cover and farming land use, was also corroborated by thermal images of the surface which reveal big temperature differences. 